\title{
Bioremediation of lead and cadmium and the strive role of Pediococcus pentosaceus probiotic
}

\author{
R.S. Jaafar \\ Biological development department, Marine Science Center, University of Basra, Basra, Iraq, amialraghad@yahoo.com
}

(Received March 29, 2019; Accepted May 13, 2019)

\begin{abstract}
Consumption of food and water contaminated with heavy metals poses a huge threat to the life. Both of Lead $(\mathrm{Pb})$ and Cadmium (Cd) are heavy metals and important environmental pollutants. Away from traditional treatments, the current study aims to adopt probiotic bacteria Pediococcus pentosaceu to treat heavy metal pollution. Present results indicated a good probiotic property of $P$. pentosaceus, where they were able to survive $\mathrm{pH}$ range from 3-9, during incubation periods 3 and 24 hours, and bile salt range $0.15-0.5 \%$ for the same period. The number of bacteria in gastric $(\mathrm{pH} 3)$ and intestinal juices $(\mathrm{pH} 8)$ after 24 hours of incubation was 390 and 205, respectively. Bacteria showed an inhibitory effect against pathogenic bacteria Salmonella $s p$. The antibiotic susceptibility test revealed them resistant to clindamycin, intermediate resistant against benzylpenicillin, ampicillin, and their sensitivity to the rest tested antibiotics. Isolated bacteria identified based on their morphology, biochemical characteristic in addition to the use of automated instrument for bacterial identification (Vitek II), and depending on the results bacteria were identified as $P$. pentosaceus. In bioremediation study, the lowest inhibitory concentration of lead and cadmium and (MIC) was done, followed by assay the removal capacity by $P$. pentosaceus, using atomic absorption spectrometry (AAS) analysis. Bacteria show high MIC (1800 and $150 \mathrm{ppm})$ for $\mathrm{Pb}$ and $\mathrm{Cd}$ respectively. With removal efficiency for $\mathrm{Pb} 62.10-68.39 \%$ in the concentrations 25 and $50 \mathrm{ppm}$, respectively, and for $\mathrm{Cd} 52.71-11.25 \%$ in the same concentrations. Depending on the present finding probiotic bacteria ( $P$. pentosaceus) can apply in the bioremediation of heavy metals in the fish ponds when contamination occurs, in addition to their tradition used as safety additive to prevent fish disease and an enhancement agent .Finally the isolation of these bacteria from fish ponds can be considered as a good indicator for a healthy state of fish ponds in the studied area.
\end{abstract}

Keywords: Probiotic properties, Pollution, Heavy metals, MIC, Biosorption Available online at http://www.vetmedmosul.com, (C) 2020, College of Veterinary Medicine, University of Mosul. This is an open access article under the CC BY 4.0 license (http://creativecommons.org/licenses/by/4.0/).

Pediococcus pentosaceus المعالجة الحيوية لكل من الرصاص والكادميوم والدور الفعال لبكتريا

$$
\text { قسم التطور الإحيائي، مركز علوم البحار ، جامعة البصرة، البصرة، العر اق }
$$

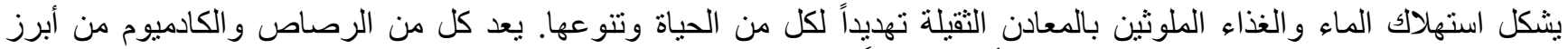

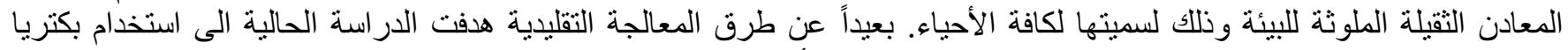
Pediococcus pentosaceus

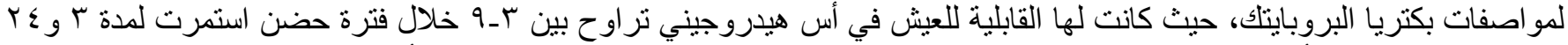

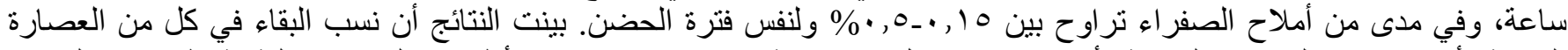

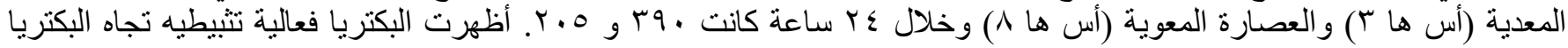




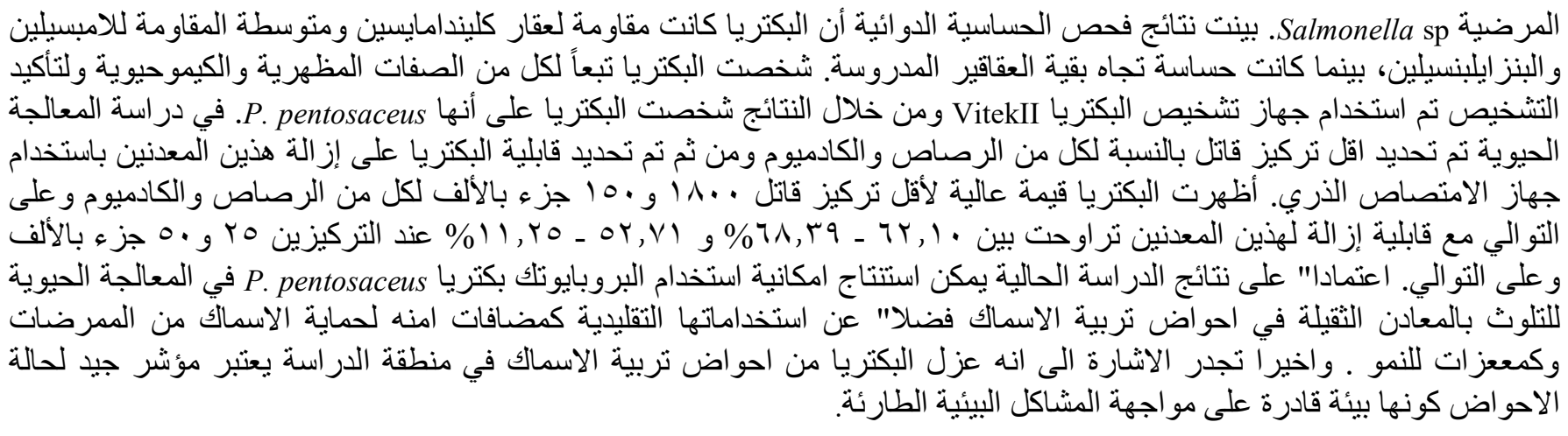

\section{Introduction}

Both of Lead $(\mathrm{Pb})$ and cadmium $(\mathrm{Cd})$ are the two great toxic heavy metals in the environment, reported in the priority list of dangerous matter on the $2^{\text {nd }}$ and $7^{\text {th }}$ places, respectively (1). They are biologically nonessential and non-degradable and tend to accumulate in exposed organisms. The aquatic environment is very susceptible to heavy metal contamination, and the gradual increase of these metals in aquatic environments has become a major problem. Fish are the water inhabitants, that can be heavily affected by heavy metals. In spite of the constitutive efforts to protect the health from hazardous heavy metals, occupational and environmental exposures to $\mathrm{Pb}$ and $\mathrm{Cd}$ remain a serious problem in many countries (2). Several modified and sophisticated techniques have emerged, including many methods of biological treatment to improve the environment contaminated with heavy metals. More recently, the use of favorable microorganisms such as probiotics has been a field that is likely to be shown to scientists in the aquaculture field to care of aquatic animals and for the conservation of the aquatic environment. In most cases, probiotic bacteria, such as lactobacilli and bifidobacterial separated from environmental samples and the digestive tract have been used as an adjunct to improve nutrition, growth, disease controls $(3,4)$, and the immune response (5). There are also many studies that have been shown that the Lactic acid bacteria (LAB) and particularly lactobacilli can bind heavy metals, so they can consider as a hopeful means for eliminating of heavy metals from food and water and may be the digestive tract as well, the extension of LAB applying in the food industry as a probiotic. Unlike classical remediation process, the binding of bacterial metal ions is nonspecific and environmentally benign, cheap, and active even at low metal ion concentrations (6). The removal of heavy metals with lactic acid bacteria (LAB) has been studied in numerous previous works (7-9). LAB is group of bacteria which give a positive reaction toward gram stains, under light microscope, they occur with rod or coccus shape. Their DNA has less than
$55 \%$ mol from $\mathrm{G}+\mathrm{C}$, they don't form spore, cannot move, microaerophilic, they fermented carbohydrates to the lactic acid as their main end product. LABs are usually presented in an environment where the nutrient is being rich such as (milk, meat, vegetables), fermented decay material and the mucosal layer of the digestive tract of organisms (10). Probiotic bacteria are the majority of microbes that can be safely used in medical and veterinary applications (11), and there's many criteria the bacteria must be achieved to be perfect as a probiotic, such as the ability to survive at low $\mathrm{pH}$ in the stomach and high concentrations of bile salts available so as to reach the hindgut in good form and effort their advantageous properties (8). One of the important properties of probiotic is its ability to improve the immune performance of the host and therefore it must have antagonistic activity against pathogens, beside their ability to live with substances that act as antibacterial agents like organic acids, heavy metals, hydrogen peroxide and antifungal compounds (12).

From the above introduction, this study intends to isolate and individualize of probiotics from fish farming and demonstrate their in vitro bioremediation ability for Lead and Cadmium.

\section{Material and methods}

\section{Collection of samples}

Nine water samples were collected from three Cyprinus carpio (common carp) fish ponds located in Marine Science Center, Basra University, Al- Garma campus, using $500 \mathrm{ml}$ glass bottles, during April 2018. Samples putted in ice box and transfer to the lab where saved under cooling $4{ }^{\circ} \mathrm{C}$ till be used. The feed used in these ponds not contain any bacterial additive, and it was confirmed that no additional supplements were added to feed of fish in these ponds.

\section{Isolation and enumeration of bacteria from water of the fish pond}

A series of dilution was performed under severe sterilization for all water samples collected, then $0.1 \mathrm{ml}$ of 
each dilution planted on the surface of de Mann Rogosa Sharpe agar medium (MRS, Hi media) (13), and then incubated aerobically at $37{ }^{\circ} \mathrm{C}$ for 48 hours. The clear bacterial colonies were taken from the plant medium to produce pure culture.

\section{Characterize of bacteria}

Morphological and biochemical tests were carried out for diagnosis the probable type of bacterial colony from MRS agar (14), and for certain the identification Vitek II (Biomerieux, USA), also has been used.

\section{Probiotic properties of the isolate}

Probiotic properties of identification bacteria, such as survive in acid, tolerance against bile salt, and tolerance to gastrointestinal juices have been studied as follows.

\section{Affording to Acid}

The acid tolerance test has been done using MRS broth with different $\mathrm{pH} 3,5,7$, and 9, which prepared using $\mathrm{HCl}$ $1 \%$ (J. T. Baker) and $\mathrm{NaOH} 1 \mathrm{~N}$ (Hi media) in addition to control flask (15), then autoclaved at $121{ }^{\circ} \mathrm{C}$ for 15 minutes (triplicate has been used for each test). $0.1 \mathrm{ml}$ of overnight cultured bacteria in MRS broth has been used to inoculate each flask, which then incubated at $30^{\circ} \mathrm{C}$. Optical density (OD) as the growth rate of bacteria was measured by a spectrophotometer (Shimadzu, UV-1800, Japan) at $600 \mathrm{~nm}$ after 3, and 24 hours incubation (9).

\section{Bile tolerance (Oxgall treatment)}

For this test MRS broth with different concentration of Oxgall bile salts (Difco) has been prepared 0.0, 0.15, 0.25, and $0.3 \%(\mathrm{w} / \mathrm{v})$. Then each concentration inoculated with $0.1 \mathrm{ml}$ from overnight cultured bacteria and incubated at 30 ${ }^{\circ} \mathrm{C}$. The growth of bacteria in each concentration has been assessed after incubation at $37{ }^{\circ} \mathrm{C}$ for 4 and 24 hours by measuring the optical density at $600 \mathrm{~nm}$ using spectrophotometer (Shimadzu, UV-1800, Japan) (16).

\section{Afford to simulate human gastrointestinal tract}

To provide in vitro situation as those found in the digestive tract, both of gastric and pancreatic juices were prepared by dissolving $3 \mathrm{mg} \cdot \mathrm{ml}^{-1}$ from pepsin (Sigma) and $1 \mathrm{mg} \cdot \mathrm{ml}^{-1}$ from pancreatin USP (Sigma- Aldrich) in sterile sodium chloride solution $(0.5 \%, \mathrm{w} / \mathrm{v})$. Hydrochloric acid (3 mol. $\left.\mathrm{L}^{-1}\right)$ and $\mathrm{NaOH}\left(1 \mathrm{~mol} . \mathrm{L}^{-1}\right)$ have been used to revising the $\mathrm{pH}$ to 3 and 8 respectively. $0.2 \mathrm{ml}$ of the overnight bacterial rinse in phosphate buffered saline $(\mathrm{pH} 7.0)$ were injected with $1.0 \mathrm{ml}$ of simulated gastric or pancreatic juice and $0.3 \mathrm{ml} \mathrm{NaCl}(0.5 \%, \mathrm{w} / \mathrm{v})$, then incubated at $37{ }^{\circ} \mathrm{C}$. Colony forming unit $(\mathrm{CFU} / \mathrm{ml})$ was counted after incubation for $180 \mathrm{~min}$ for gastric tolerance, and $240 \mathrm{~min}$ for basic $\mathrm{pH}$ tolerance (17).

\section{Antibacterial test}

Freshwater fish pathogens, Salmonella $s p$. were used to study the antibacterial ability of probiotic bacteria using well diffusion techniques. Shortly, $1 \mathrm{ml}$ of overnight culture of Salmonella $s p$ in Tryptone soya broth (TSB, Hi media) was distributed through sterile loop on tryptone soy agar (TSA, Hi media). A probiotic suspension used as an antibacterial agent was obtained from a 24 hours bacterial culture after being centrifuged at $3000 \mathrm{rpm}$ for 5 minutes (16).

\section{Antibiotic susceptibility test}

Automated way using Vitek II, were applied to study the sensitivity of probiotic against many antibiotics. The tests are run similarly on cards which have of attenuation of antimicrobials to appoint the break point, which mentioned to the minimum inhibitory concentration (MIC) of antibiotic.

\section{Heavy Metal Tolerance Assays Preparation of heavy metals concentrations}

To prepare stock solutions from the heavy metal salts, the exact weight of $\mathrm{Pb}\left(\mathrm{NO}_{3}\right)_{2}$ and $\mathrm{Cd}\left(\mathrm{NO}_{3}\right)_{2} \mathrm{H}_{2} \mathrm{O}$ were dissolved in sterile deionized distilled water. Then suitable serial dilution of these stock solutions was used to make different concentrations of $\mathrm{Cd}$ (II) and $\mathrm{Pb}$ (II) (18).

\section{The lowest inhibitory concentration}

This test usually used to detect the ability of bacteria to tolerate heavy metals. Loopful of the overnight growing probiotic bacteria in MRS broth (MRS, Hi media), at $37^{\circ} \mathrm{C}$, was taken aseptically and streaked onto a plate of MRS agar supplemented with various concentrations of $\mathrm{Cd}$, and $\mathrm{Pb}(25,50,100,250,500,1000,1500,1800$ and 2000 ppm). The plates were then incubated at $37^{\circ} \mathrm{C}$ for 48 hours. A colony or limited growth was ignored. The lowest concentration of heavy metals leading to growth inhibition was determined to be the MIC. This procedure was carried out in triplicate, as one of them was control (19).

\section{Biosorption study}

$2 \mathrm{ml}$ of the overnight bacterial pending was used to vaccinate MRS broth appended with 25 and $50 \mathrm{ppm}$ of $\mathrm{Cd}$, and $\mathrm{Pb}$, Then the broth nestles at $37{ }^{\circ} \mathrm{C}$ for $24 \mathrm{hrs}$. After that broth has been centrifuged at $3000 \mathrm{rpm}$ for $20 \mathrm{~min}$, the supernatant was used to assay $\mathrm{Cd}$, and $\mathrm{Pb}$ removal by bacteria using flame atomic absorption spectrophotometer (AAS 6300, Shimadzu, Japan). This experiment has been done in triplicate as one of them was control. The bacterial efficiency in remove $\mathrm{Cd}$, and $\mathrm{Pb}$ was calculated as percentage of removal using the equation below:

$\%$ Removal $=($ decline in HM concentration $\div$ Initial HM concentration) $\times 100$ Where, HM means heavy metal (19). 


\section{Results}

\section{Isolation and identification of $P$. pentosaceus}

During the current search, only the isolate that gave positive reactions to gram stain and negative reaction to catalase were selected for additional diagnosis. The bacteria have been identified as $P$. pentosaceus through its phenotypic, culture characteristics, and based on biochemical tests. The colony properties of these bacteria were examined by aseptically handling, colony and transferred it to the selective medium (medium MRS) to monitor the growth pattern of the isolates. The colonies were creamy white, circular, low convex with a full rim were regarded as belonging to the genus $P$. pentosaceus (Table 1). and for more confirmation it's identified by Vitek II, with confidence degree $95 \%$.

Table 1: Morphological, and biochemical properties of the bacteria

\begin{tabular}{lc}
\hline Colony Morphology & \\
\hline Configuration & Round \\
Cell shape & Round \\
Motility & Non motile \\
Pigment & White Creamy \\
Gram reaction & + \\
Surface & Mucoid \\
\hline Biochemical Tests & \\
\hline H2S formation & - \\
Catalase & - \\
Nitrate reduction & - \\
Urease & - \\
Indole Production & + \\
Methyl red test & + \\
V. P. Reaction & + \\
Citrate utilization & + \\
\hline Acid Production from & + \\
\hline Glucose & + \\
Lactose & + \\
Maltose & + \\
\hline
\end{tabular}

\section{Acid tolerance test}

The results in Table 2 showed that the growth of bacteria appeared during a range of $\mathrm{pH} 3-9$, and during three and 24 hours, duration. These results indicated that $P$. pentosaceus having the most important feature of probiotic bacteria, which is their ability to alive in stomach where high acidity.

\section{Tolerance against Bile salt}

To be ensured from bile salts tolerance in the studied bacteria, they were analyzed to a greater extent for their ability to survive at different concentrations of bile salt
$(0,0.15,0.25$ and $0.5 \%)$, and during different incubation period ( 3 and 24 hours) results showed the capacity of the bacteria to survive under studied concentrations of bile salts, however, the growth of bacteria decreased with the increase concentration of bile salt also their survive were less in 24 hours of incubation than this in 3 hours (Table 2).

\section{Probiotic survival in gastric and intestinal juices}

The probiotic survival rate in both gastric and pancreatin juices was as shown in the table 2, results showed that bacteria could survive in both juices $(\mathrm{pH} 3$ and $\mathrm{pH} 8$ ) during 24 hours, with efficient survive in $\mathrm{pH} 3$ than in $\mathrm{pH} 8$.

\section{Detection of antimicrobial activity}

Result showed that the cell free solution of $P$. pentosaceus was able to inhibit the growth of pathogenic bacteria Salmonella sp.

\section{Antibiotic susceptibility in $\boldsymbol{P}$. pentosaceus}

Table 2, shows the MIC values obtained for the different antibiotics tested in the studied bacteria. To determine whether an organism is sensitive, mild opponent or opponents to antimicrobials, the break value of MIC is adopted. From results we can conclude that the understudying bacteria was sensitive to the most studied antibiotics with differ in MIC value, whereas it was resistance to only inducible Clindamycin.

\section{Metal resistant pattern}

In order to evaluate the bioremediation ability of the isolates, bacteria were investigated for their tolerance to different concentrations of $\mathrm{Pb}$, and $\mathrm{Cd}$ by assessing their minimal inhibitory concentrations (MICs). Results of MIC values were shown in the Table3. As it can be seen from the results, the value of MIC was greater for $\mathrm{Pb} 1800 \mathrm{ppm}$ than this for $\mathrm{Cd} 150 \mathrm{ppm}$. In this context, it may be inferred although $P$. pentosaceus was resistant against $\mathrm{Pb}$ and $\mathrm{Cd}$, but it was more resistant to $\mathrm{Pb}$ than $\mathrm{Cd}$. In bioremediation study two concentration 25 and $50 \mathrm{ppm}$ from $\mathrm{Pb}$ and $\mathrm{Cd}$ has been used and Results in (Table 3) indicated that the percentage of $\mathrm{Pb}$ removal were 62.10 and $68.39 \%$ for the concentration 25 and 50 ppm respectively, and for $\mathrm{Cd}$ they were 52.71 and $11.25 \%$. Results also indicated that the studied bacteria were able to remove $\mathrm{Pb}$ more than their ability in removing $\mathrm{Cd}$. Another conclusion can be added, the ability of bacteria to remove $\mathrm{Pb}$ increases with increased concentration, while $\mathrm{Cd}$ removal decreases with increased concentration, which means that $\mathrm{Cd}$ removal ability is concentration dependent, from the highest $\mathrm{Cd}$ concentration (50 ppm) a smaller fraction was removed than from the 25 ppm. 
Table 2: Effect of both $\mathrm{pH}$ and concentration of bile salts in the survival of $P$. pentosaceus, the number of bacteria in gastric and intestinal juices, and Antibiotic sensitivity pattern of various antibiotics

\begin{tabular}{|c|c|c|}
\hline Medium $\mathrm{pH}$ & $\begin{array}{c}\text { Optical density } \\
(600 \mathrm{~nm}) \text { (3 hours) }\end{array}$ & $\begin{array}{c}\text { Optical density } \\
(600 \mathrm{~nm})(24 \text { hours })\end{array}$ \\
\hline 3 & 0.564 & 0.327 \\
\hline 5 & 0.886 & 0.639 \\
\hline 7 & 1.629 & 1.687 \\
\hline 9 & 1.511 & 1.645 \\
\hline Bile salt $\%$ & $\begin{array}{c}\text { Optical density } \\
(600 \mathrm{~nm})(3 \text { hours })\end{array}$ & $\begin{array}{c}\text { Optical density } \\
(600 \mathrm{~nm})(24 \text { hours })\end{array}$ \\
\hline Zero & 1.686 & 1.557 \\
\hline 0.15 & 0.161 & 0.568 \\
\hline 0.25 & 0.132 & 0.398 \\
\hline \multirow[t]{3}{*}{0.5} & 0.125 & 0.239 \\
\hline & $\begin{array}{l}\text { Number of bacteria } \\
\text { in gastric juice } \\
\text { (pH 3) (24 hours) }\end{array}$ & $\begin{array}{l}\text { Number of bacteria in } \\
\text { intestinal juice } \\
(\mathrm{pH} 8)(24 \text { hours })\end{array}$ \\
\hline & 390 & 205 \\
\hline Antimicrobial & $\mathrm{MIC}$ & Interpretation \\
\hline Benzylpenicillir & 1 & $\mathrm{I}$ \\
\hline Ampicillin & 0.5 & I \\
\hline Cefotaxime & 0.5 & S \\
\hline Ceftriaxone & 1 & $\mathrm{~S}$ \\
\hline Levofloxacin & 2 & $\mathrm{~S}$ \\
\hline Clindamycin & & $\mathrm{R}$ \\
\hline Erythromycin & $<=0.12$ & S \\
\hline Clindamycin & $<=0.25$ & S \\
\hline Linezolid & $<=2$ & $\mathrm{~S}$ \\
\hline Vancomycin & 0.25 & $\mathrm{~S}$ \\
\hline Tetracycline & 0.5 & $\mathrm{~S}$ \\
\hline
\end{tabular}

Table 3: The minimum inhibitory concentration (ppm), and heavy metals removal (\%)

\begin{tabular}{lccc}
\hline Heavy & \multirow{2}{*}{ MIC (ppm) } & \multicolumn{2}{c}{ Heavy metals removed (\%)/24h } \\
\cline { 3 - 4 } metals & & $25 \mathrm{ppm}$ & $50 \mathrm{ppm}$ \\
\hline $\mathrm{Pb}$ & 1800 & 62.10 & 68.39 \\
$\mathrm{Cd}$ & 150 & 52.71 & 11.25 \\
\hline
\end{tabular}

\section{Discussion}

Depending on the traditional way included the morphological and biochemical tests the isolated bacteria in present study has been identified as $P$. pentosaceus, and this finding also emphasis by using the Vitek II, which gave us result with confidence degree $95 \%$. This results covenant with the results recorded by Ayo-Olalusi (6). Different feature related to good probiotic properties of bacteria has been studied. The high acidity in the stomach is considered one of the most important elements that can affect the survival of probiotics (20). Therefore, to be ensure from probiotic properties, testing their viability and functionality in acidic conditions must be defended, possessing this property is very important as probiotic bacteria have to pass through the stomach were strongly acidic condition found to arrive the intestines. Nevertheless, probiotic bacteria have different susceptibility to acidify depending on their types and strains and strain dependent (21).

Good probiotic sources must at least stay alive at $\mathrm{pH} 3$ (22), because of the high acidity in the stomach. The present finding revealed that these bacteria were able to survive in extreme acidic condition, and these outcomes harmonize with the results reported by (23), and can be proved that the studied bacteria have one of the most selective standards for probiotic bacteria (24). Acid tolerance in probiotic bacteria also reported in other studies, Damayanti et al. (25) reported the viability of lactic acid bacteria Lactobacillus plantarum was $92.61 \%$ at $\mathrm{pH} 3$ after 90 minutes. Raghad et al. (26) reported that the all isolates of pediococcus bacteria have the ability to survive in acidic conditions for 3 hour and 24 hours. The study of resistance to bile salts by probiotic bacteria consider extremely important, that the one of the most important features in the probiotic bacteria is their tolerance to the bile salts, because bile salts can act as antibacterial agents towards normal flora (21). Ability to survive in the bile salt also has been studied, and bacteria showed good ability to survive in a bile salt concentration $0,0.15,0.25$ and $0.5 \%$, but with an increase the bile salt concentration the bacterial survive decrease. Similar results were recorded by Allameh et al (9), where they find out, significant decrease in the growth of $L$. mesenteroides by increasing bile salt concentration. Also, Sukumar and Ghosh (27) reported that Pediococcus spp. which were isolated from an Indian fermented food showed meaningful bile tolerance. Shin et al. (28) finds out that the $P$. pentosaceous SH740 isolated from GIT of broiler chickens were survive in the $0.5 \%$ bile salts and stay viable after 2 hours at $\mathrm{pH} 3$. The combined effect of the pepsin $(\mathrm{pH} \mathrm{3)}$ solution and the pancreatin solution $(\mathrm{pH} \mathrm{8})$ was intended to simulate the gastric and intestinal juice respectively. Results indicated that the bacteria could survive in both solutions, however their survive was more in gastric solution than in pancreatin solution. Similarly, Grimoud et al. (29) reported that Lactobacillus strains have more survival rates under gastric conditions than the survival rate in the intestines. Tokatl et al. (30) also reported that they all studied strain of $L$. plantarum and $L$. brevis more resistance to intestinal conditions than gastric juice. Probiotic also showed good inhibition action towered pathogenic bacteria. The inhibition of pathogenic bacteria is due to the inhibitory action of the extracellular and to diffusible metabolites by $P$. pentosaceus. These findings are appropriate for those who have been indicated by $(31,32)$. Antibiotic sensitivity pattern of $P$. pentosaceous against 
various antibiotics has been studied and results indicated that the bacteria was sensitive to the most studied antibiotics with differ in MIC value, whereas it was resistance to only inducible Clindamycin, in this respect Klare et al (33) have been identified the MICs from 16 antimicrobials for 473 isolates of LAB, including Lactobacillus, Pediococcus and Lactococcus, and results proved that the vast majority of LAB were sensitive towards penicillin, ampicillin, ampicillin / sulbactam, quinupristin / dalfopristin, chloramphenicol and linezolid, where's, the resistant to streptomycin occur in three strains of the probiotic. Another study has found that Lactobacillus species are affected by many inhibitors of cell wall synthesis, such as penicillin and ampicillin. Munoz-Atienza et al (34) reported that $P$. pentosaceus LPP32, LPM83 and B5 were clindamycin resistant.

The MIC is defined as the minimum concentration of a heavy metal at which microbial growth is completely inhibited due to its effect (35). To assess the ability of bacteria to remediate heavy metals it's important to determine the minimum inhibitory concentration, in present study $P$. pentosaceous showed a high value of MIC for both $\mathrm{Cd}$ and $\mathrm{Pb}(150$ and $1800 \mathrm{ppm})$ respectively, however the $\mathrm{MIC}$ was more for $\mathrm{Pb}$ than for $\mathrm{Cd}$. This can be attributed to the high concentration of lead in the environment, which made the bacteria more resistant to $\mathrm{Pb}$ than $\mathrm{Cd}$. Similarly, Bhakta et al (36) proved ability of six isolated from Pediococcus dextrinicus and Pediococcus acidilactici to tolerance, high concentration of $\mathrm{Pb}<1000$, for all isolated, where's the MIC value for a $\mathrm{Cd}$ range from 50 to 250 for the six isolates. Li et al (37) reported that the MIC value for $\mathrm{Pb}$ by L. bulgaricus KLDS10207 was $>1000$. Since the bacteria under study showed high tolerance for both $\mathrm{Pb}$ and $\mathrm{Cd}$, so they were used in the study of removing of these two metals using different concentration 25 and $50 \mathrm{ppm}$, and during 24 hours. Bioremediation ability of $P$. pentosaceous indicated ability of this bacteria to remove both $\mathrm{Cd}$ and $\mathrm{Pb}$. Like other gram positive bacteria, Lactobacillus cell surface contains different charge group like carboxyl, hydroxyl, and phosphate which result from the complex component of their cell wall (thick peptidoglycan layer, (lipo) teichoic acids, polysaccharides, and proteins, including S-layer (glycol) proteins (19), and as a consequence they have large number of ligand that can binding cations such as $\mathrm{Cd}$ and $\mathrm{Pb}$. Results also showed that $P$. pentosaceous was more efficient in remove $\mathrm{Pb}$ than $\mathrm{Cd}$. This can be attributed to having a high MIC value for $\mathrm{Pb}$ than this for $\mathrm{Cd}$, which may be responsible for developing the possibilities of bacteria in removing $\mathrm{Pb}$. In the same context (36) showed that $\mathrm{Pb}$ and $\mathrm{Cd}$ resistant. Lactobacillus strains were more efficient in remove $\mathrm{Pb}$ than $\mathrm{Cd}$. In the same context (38) reported that the $\mathrm{Pb}$ removal by L. bulgaricus KLDS10207 reach to $79.18 \%$ with the initial $\mathrm{Pb}$ concentration $50 \mathrm{ppm}$. Results indicated that the $\mathrm{Cd}$ removal by bacteria was concentration dependent where it was decrease with increase the concentration, and this agree with (39). At a concentration of $10 \mu \mathrm{g} / \mathrm{l}$ up to $70 \%$ could be removed within 5 minute, and up to $90 \%$ after 1 hour, but at a concentration of $1000 \mu \mathrm{g} / \mathrm{l}$ between 5 and $30 \%$ was removed after 5 minute and between 20 and $55 \%$ after 1 hour (7), reported that the binding of both $\mathrm{Cd}$ and $\mathrm{Pb}$ by all studied stain of LAB, were ranged between $61.8-87.8 \%$ and $30.2-92.6 \%$, respectively.

\section{Conclusions}

In this study, by morphological and biochemical investigation, isolated bacteria were identified as $P$. pentosaceus and the results were verified using VitekII. The bacteria undergo various tests to evaluate their probiotic characteristics. All were acids, bile and gastrointestinal tolerance. Analogous features of antibiotic susceptibility have been observed during this study and the bacteria have an antibacterial activity against the bacteria test indicator, and from the result can be concluded that they have perfect probiotic properties. And the results of bioremediation study indicated their ability to tolerate high concentration of $\mathrm{Pb}$, and $\mathrm{Cd}$, where the MIC was 1800 and $150 \mathrm{ppm}$ respectively. Subsequently, an expanded flame AAS analysis was acted to report the removal of heavy metals by bacteria. The bacteria show a reasonable elimination of both $\mathrm{Cd}$, and $\mathrm{Pb}$. It can be concluded that $P$. pentosaceus has efficiency in removing both of $\mathrm{Cd}$, and $\mathrm{Pb}$ from broth culture emended with different concentration 25 and 50 ppm of $\mathrm{Cd}$, and $\mathrm{Pb}$. Thus, the presence of these bacteria in fish ponds is of great importance in removing heavy metals as well as their role as the basis food supplements.

\section{Acknowledgments}

I would like to thank the Lab of Marine Bacteriology, Marine Science Center, University of Basra for all the facilities which introduce to me in this work.

\section{References}

1. Agency for toxic substances and disease registry guidance for the preparation of a twenty first set toxicological profile. 2007. Available online: http://www.atsdr.cdc.gov/toxprofiles/guidance.pdf.

2. Jaafar R, Al-Sulami A, Al-Taee A, Aldoghachi F, Suhaimi N, Mohammed S. Biosorption of some heavy metals by Deinococcus radiodurans isolated from soil in Basra governorate, Iraq. J Bioremediat Biodegrad.2016;7(2). doi: 10.4172/2155-6199.1000332.

3. Fenchel T, Kofoed L. Evidence for exploitative interspecific competition in mud snails (Hydrobiidae). Oikos. 1976;27(3):367-376. doi: $10.2307 / 3543455$.

4. Sugita H, Okano R, Suzuki Y, Iwai D, Mizukami M, Akiyama N, Matsuura S. Antibacterial abilities of intestinal bacteria from larval and juvenile Japanese flounder against fish pathogens. Fish Sci. 2002;68(5):1004-1011.doi.org/10.1046/j.1444-2906. 
5. Sugita H. Antibacterial abilities of intestinal bacteria from three coastal fishes. Aquacul Sci. 1998;46:563-568.

6. Ayo-Olalusi CI. Isolation and identification of probiotics Pediococcus pentosaceus from the gut of tilapia guineensis for use in aquaculture production. Intern J Res Stud Microbiol Biotechnol. 2017;3(1):15-20. doi.org/10.20431/2454-9428.0301004.

7. Halttunen T, Kankaanpa P, Tahvonen R, Salminen S, Ouwehand AC. Cadmium removal by lactic acid bacteria. Biosci Microflora. 2003;22(3):93-97. doi.org/10.12938/1996.2293.

8. Elsanhoty RM, Al-Turki I, Ramadan MF. Application of lactic acid bacteria in removing heavy metals and aflatoxin B1 from contaminated water. Water Sci Technol. 2016;74(3):625638.doi.org/10.2166/wst.2016.255.

9. Allameh SK, Daud H, Yusoff FM, Saad CR, Ideris A. Isolation, identification and characterization of Leuconostoc mesenteroides as a new probiotic from intestine of snakehead fish (Channa striatus). Afr J Biotechnol. 2012;11(16):3810-3816.doi.org/10.5897/AJB11.1871.

10. Salminen, S. (Ed.), von Wright, A. (Ed.). Lactic Acid Bacteria. Boca Raton: CRC Press,2004. doi.org/10.1201/9780824752033.

11. .Rauta PR, Dhupal M, Nayak B. Screening and characterization of potential probiotic lactic acid bacteria isolated from vegetable waste and fish intestine. Int J Curr Microbiol App Sci. 2013;2:234244.doi.org.10.1590/s1517-82832011000400039.

12. Ghosh S, Ringo E, Selvam ADG, Rahiman KM, Sathyan N, John N, Hatha AM. Gut associated lactic acid bacteria isolated from the estuarine fish Mugil cephalus: Molecular diversity and antibacterial activities against pathogens. Inter $J$ Aquac. 2014;4(1):1-11. doi.org/10.5376/ija.2014.04.0001.

13. De Man J, Rogosa D, Sharpe ME. A medium for the cultivation of lactobacilli.JApplBacteriol.1960;23(1):130-135doi.org/10.1111/j.13652672.1960.tb00188.

14. Holt JG, Krieg N. Bergey's manual of systematic bacteriology. Baltimore: The Williams and Wilkins Co; 1984. 1-13 p.

15. Samelis J, Maurogenakis F, Metaxopoulos J. Characterization of lactic acid bacteria isolated from naturally fermented Greek dry salami. Int $\mathrm{J}$ Food Microbiol. 1994;23(2):179-196. doi.org/10.1016/01681605(94)90051-5

16. Balcazar JL, Vendrell D, de Blas I, Ruiz I, Muzquiz JL, Girones O. Characterization of probiotic properties of lactic acid bacteria isolated from intestinal microbiota of fish. Aquac. 2008;278(1-4):188-191. doi.org/10.1016/j.03.014.

17. Charteris WP, Kelly PM, Morelli L, Collins JK. Selective detection, enumeration and identification of potentially probiotic Lactobacillus and Bifidobacterium species in mixed bacterial populations. Int J Food Microbiol.1997;35(1):127.doi.org/10.1016/S0168-1605(96)01222-6.

18. Etorki AM, El-Rais M, Mahabbis MT, Moussa NM. Removal of some heavy metals from wastewater by using of fava beans. Am J Analyt Chem. 2014;5(04):225. doi.org/10.4236/ajac/54028.

19. Huet MAL, Puchooa D. Bioremediation of heavy metals from aquatic environment through microbial processes: A potential role for probiotics? J Appl Biol Biotechnol. 2017;5(6):1423.doi.org/10.7324/JABB/.506033.

20. Menconi A, Kallapura G, Latorre JD, Morgan MJ, Pumford NR, Hargis $\mathrm{BM}$, Tellez G. Identification and characterization of lactic acid bacteria in a commercial probiotic culture. Biosci Microbiol Food Health. 2014;33(1):25-30.doi.org/10.12938/bmfh.33.25

21. Fontana L, Bermudez M, Plaza J, Munoz S, Gil A. Sources, isolation, characterization and evaluation of probiotics. $\mathrm{Br} \mathrm{J}$ Nutr.2013;109(S2):S35-S50. doi.org/10.1017/S0007114512004011.

22. Fernandez M, Boris S, Barbes C. Probiotic properties of human lactobacilli strains to be used in the gastrointestinal tract. J Appl Microbiol.2003;94(3):449-55.doi.org/10.1046/j.13652672.2003.01850.x.

23. Davati N, Yazdi FT, Zibaee S, Shahidi F, Edalatian MR. Study of lactic acid bacteria community from raw milk of Iranian one humped camel and evaluation of their probiotic properties. Jundishapur J Microbiol. 2015;8(5):e16750.doi.org:105812/jjm 8(5)2015.16750.

24. Cakir I. Determination of some probiotic properties on Lactobacilli and Bifidobacteria. Ankara Univrsity thesis of Ph.D.2003.

25. Damayanti LI, Saragih JE, Purwoko T, Sardjono. Characterization of lactic acid bacteria as poultry probiotic candidates with aflatoxin B1 binding activities. Earth Environ Sci. 2017;12(3):1-9. doi.org/10.1088/1755-1315/101/1/012030.

26. Raghad S. Jaafar, Fadhil N. Al-knany, Bayan M. Mahdi and Asaad M.R. Al-Taee, Study the Probiotic Properties of Pediococcus pentosaceus Isolated from Fish Ponds in Basra City-South of Iraq, $J$ Pure Appl Microbiol.,2019; 13(4): doi: 10.22207/JPAM.13.4.

27. Sukumar G, Ghosh AR. Pediococcus spp. a potential probiotic isolated from Khadi (an Indian fermented food) and identified by 16S rDNA sequence analysis. Afr J Food Sci. 2010;4(9):597-602. doi.org/10.5897/AJFS2019.1826.

28. Shin M, Han S, Ji A, Kim K, Lee W. Isolation and characterization of bacteriocin-producing bacteria from the gastrointestinal tract of broiler chickens for probiotic use. J Appl Microbiol. 2008;105(6):2203-2212. doi.org/10.1111/j.1365-2672.2008.03935.x.

29. Grimoud J, Durand H, Courtin C, Monsan P, Ouarne F, Theodorou V, Roques C. In vitro screening of probiotic lactic acid bacteria and prebiotic glucooligosaccharides to select effective symbiotic. Anaerobe. 2010;16(5):493-500. doi.org/10.1016/j.anaerobe.2010.07.005.

30. Tokatl M, Gulgor G, Bagder S, Arslankoz N, Ozcelik F. In vitro properties of potential probiotic indigenous lactic acid bacteria originating from traditional pickles. Biol Med Res Inter. 2015;31(5):18.doi.org/10.1155/2015/315819.

31. Bartkiene VK, Antanaitis J, Kantautaite A, Kucinskas M, Ruzauskas L, Vaskeviciute R, Siugzdiniene J, Kucinskiene J, Damasius G, Juodeikiene S. Antimicrobial activity of lactic acid bacteria multiplied in an alternative substrate and their influence on physiological parameters of new-born calves. Vet Med. 2016;61:653-662. doi.org/10.17221/192/2015-VETMED

32. Dalia C, Grazina J, Algimantas P, Elena B. Antimicrobial activity of lactic acid bacteria against pathogenic and spoilage microorganism isolated from food and their control in wheat bread. Food Control2013;31:539-545. doi.org/10.1016/j.foodcont.2012.12.004.

33. Klare I, Konstabel C, Werner G, Huys G, Vankerckhoven V, Kahlmeter G, Hildebrandt B, Muller S, Witte W, Goossens H. Antimicrobial susceptibilities of Lactobacillus, Pediococcus and Lactococcus human isolates and cultures intended for probiotic or nutritional use. J Antimicrob Chemother. 2007;59(5):900912..doi.org/10.1093/jac/dkm035.

34. Munoz E, Gomez B, Araujo C, Campanero C, del Campo R, Hernandez PE, Herranz C, Cintas LM. Antimicrobial activity, antibiotic susceptibility and virulence factors of lactic acid bacteria of aquatic origin intended for use as probiotics in aquaculture. BMC Microbiol. 2013;13(1):15.doi.org/10.1186/1471-2180-13-15.

35. Yilmaz. E. Metal tolerance and biosorption capacity of Bacillus circulans strain EB1. Res Microbiol. 2003:409-415. doi.org/10.1016/S0923-2508(03)00116-5

36. Bhakta JN, Ohnishi K, Munekage Y, Iwasaki K. Isolation and probiotic characterization of arsenic-resistant lactic acid bacteria for uptalking arsenic. Inter J Chem Biol Eng. 2010;3(4):167-74.

37. Li B, Jin D, Yu S, Etareri S, Muhammad Z, Huo G, Liu F. In vitro and in vivo evaluation of Lactobacillus delbrueckii subsp. bulgaricus KLDS10207 for the alleviative effect on lead toxicity.Nutr.2017;9(8):845.doi.org/10.3390/nu9080845.

38. Li J, Naidu R. Risk assessment of heavy metal contaminated soil in the vicinity of a lead/zinc mine. J Environ Sci. 2005;17(6):881-885.

39. Teemu H, Seppo S, Jussi M, Raija T, Kalle L. Reversible surface binding of cadmium and lead by lactic acid and bifidobacteria. Inter. J. Food Microbiol.2008;125(2):170175.doi.org/10.1016/j.ijfoodmicro.2008.03.041. 